\title{
EFFECT OF A MICROBIAL-BASED ACARICIDAL PRODUCT ON SPOTTED AND PREDATORY SPIDER MITES
}

\author{
M. LAGZIRI and A. EL AMRANI \\ Group of Agro-ecology and Plant Protection, Department of Biology, Faculty of Science and Technics, \\ Tangier, Morocco
}

(Received 3 March, 2009; accepted 30 August, 2009)

\begin{abstract}
Tetranychus urticae is one of the most important pests of strawberry cultures in Morocco. Current control of this pest relies almost exclusively on acaricides. Unfortunately, this mite has developed resistance to most of the available acaricides. Moreover, insecticide treatments are responsible for the reduction or suppression of beneficial species such as natural predators. Thus, identification of selective pesticides that are more toxic to pest species than on natural enemies, is urgently needed. This study assessed the effectiveness of abamectin, a microbial-based miticide, and bifenthrin, a synthetic one, on two-spotted spider mites, Tetranychus urticae and predatory mites, Phytoseiulus persimilis. Laboratory tests were conducted to determine the direct and residual effects of two miticides (abamectin and bifenthrin) at several doses in geometric progression. Firstly, the direct efficacy of the two acaricides was evaluated against $T$. urticae and $P$. persimilis. Abamectin had high efficacy on T. urticae and significantly less toxicity against P. persimilis. Results indicated an effective control of $T$. urticae, at least 2 weeks after abamectin foliar application. Thus, abamectin could be recommended as a selective acaricide in integrated mite management programmes because of its strong efficacy on pests, its persistence and its limited toxicity on predatory mites.
\end{abstract}

Key Words: Tetranychus urticae, Phytoseiulus persimilis, abamectin, bifenthrin, acaricides efficacy, strawberry cultures

\section{RÉSUMÉ}

Tetranychus urticae représente le ravageur le plus important des cultures de fraises au Maroc. Le contrôle courrant de ce ravageur est presque relié à l'usage des acaricides. Malheureusement, cet acarien a développé une résistance à l'égard de la plupart des acaricides disponibles. En plus, les traitements aux insecticides sont responsables de la réduction ou suppression des espèces bénéfiques comme les prédateurs naturels. L'identification de pesticides sélectifs, plus toxiques sur les espèces de ravageurs que sur leurs ennemies naturels, est, de ce fait, urgemment recommandée. Dans l'étude décrite ici, nous avons testé l'efficacité de l'abamectine, un acaricide d'origine microbienne et la bifenthrine, un acaricide synthétique, sur les tétranyques à deux points Tetranychus urticae et sur les acariens prédateurs, Phytoseiulus persimilis. Des tests de laboratoire sont menés afin de déterminer les effets directs et résiduels des deux acaricides, appliqués en plusieurs doses variant selon une progression géométrique. L'efficacité directe des deux acaricides contre $T$. urticae et $P$. persimilis est évaluée. Nos résultats montrent que l'abamectine présente une haute efficacité sur $T$. urticae et une toxicité significativement moins importante à l'égard de $P$. persimilis. L'activité résiduelle des résidus des acaricides sur les acariens a, de même, été évaluée. Les résultats indiquent que l'efficacité de l'abamectine sur T. urticae persiste au moins deux semaines après son application sur les feuilles. Vue sa haute efficacité sur les ravageurs, sa persistance et sa faible toxicité sur les acariens prédateurs, l'abamectine peut, donc, être recommandé comme acaricide sélectif dans les programmes de gestion intégrée des acariens.

Mots Clés: Tetranychus urticae, Phytoseiulus persimilis, abamectine, bifenthrine, efficacité des acaricides, cultures de fraises 


\section{INTRODUCTION}

Application of pesticides is a popular method for controlling arthropod pests in many agroecosystems. If used properly, they can control high populations of the spotted spider mite, Tetranychus urticae Koch. This mite is an important agricultural pest with a global distribution. Its phytophagous nature, high reproductive potential and short life cycle facilitate rapid resistance development to many acaricides often after a few applications (Devine et al., 2001; Stumpf and Nauen, 2001). Moreover, insecticide treatments are responsible for the reduction or suppression of benefical species such as natural predators.

Predatory mites in the Acari family, Phytoseiidae, are often effective management components of agricultural systems (Hoy et al., 1983; Van Lenteren and Woets, 1988). Phytoseiulus persimilis (Acari, Phytoseiidae) is widely used in biological programmes throughout the world (Cho et al., 1995; McMurtry and Croft, 1997). However, several studies indicated that, despite the effectiveness of phytoseiid predators for biological control of spider mites on their host plants, the predators alone may not be able to maintain spider mite populations below an economic injury level for an extended period of time (Kim et al., 1997). Currently, great efforts are directed towards reduction in the use of traditional pesticides and towards increase in the use of Integrated Pest Management (IPM) techniques. Therefore, the search for pesticides that are compatible with IPM programmes is an interesting approach.

Abamectin is a naturally derived substance produced by a soil bacterium Streptomyces avermitilis. This product is currently used in the United States of America and Europe to control insects and mites in several crops (Andrei, 2005; Sato et al., 2005). In Morocco, abamectin has been recently used for mites control in various strawberry producing areas, particulary in the area of Loukkos. Understanding the effects of this natural product and the impact of its residues on leaf surfaces on $T$. urticae is important for this pest management in Morocco. The selectivity of abamectin against benefical arthropods should also be considered. Knowledge of abamectin selectivity to predatory mites is important to their utilisation in IPM programmes. Studies of both abamectin and bifenthrin effects on Moroccan populations of phytophagous mites T. urticae and their predators $P$. persimilis are scarce.

The aim of this study was to determine the contact effect of abamectin on mortality of $T$. urticae. Abamectin direct efficacy was compared with bifenthrin, a synthetic pyrethroid insecticide/ miticide with a range of agricultural uses.

\section{MATERIALS AND METHODS}

Mite strains. Five strains of T. urticae and four of $P$. persimilis were collected from commercial strawberry fields in the Loukkos region of Morocco. After collection, the mites were reared continuously on bean plants, under laboratory conditions at $25 \pm 1^{\circ} \mathrm{C}, 70 \pm 5 \%$ relative humidity and for a $14 \mathrm{hr}$ photoperiod. $P$. persimilis strains were elevated on bean plants infested with $T$. urticae.

Miticides. Vertimec (18 g of abamectin $\mathrm{l}^{-1}$ ) and Talstar (100 g of bifenthrin $\mathrm{l}^{-1}$ ) were tested. Six doses of abamectin (2-9 ppm) and seven doses of bifenthrin (15- $150 \mathrm{ppm}$ ) were used. The recommended field concentration for abamectin and bifenthrin are 9 ppm and 50 ppm, respectively.

Direct acaricide efficacy. These tests were based on the method described by Knight et al. (1990).Ten adult females of T. urticae were placed on a bean leaf disc ( $4 \mathrm{~cm}$ diameter) on water soaked cotton in a petri-dish (9 $\mathrm{cm}$ diameter). The prepared suspension of acaricide $(2 \mathrm{ml})$ was sprayed onto the leaf disc mites. For each acaricide, several doses were used in geometric progression. An untreated control was also used for statistical purposes. Thereafter, the mites on the leaf disc were kept at $25 \pm 1^{\circ} \mathrm{C}$ and a $14 \mathrm{hr}$ photoperiod for $24 \mathrm{hr}$ after treatment. Individual mite survival was determined by touching each mite with a fine brush. Mites which were unable to move at least a distance equivalent to their body length were considered dead.

The experiment was repeated five times. The effects of acaricides on adults of $P$. persimilis were evaluated in the same way as it was for $T$. urticae. 
Residual acaricide efficacy. The effect of acaricide residues against $T$. urticae was evaluated at $0,7,14$ and 21 days after treatment. Three abamectin doses were used $(5,7$ and 9 $\mathrm{ppm})$. Bean plants were treated with each of the abamectin doses. The leaves that were sprayed with miticide suspension were marked with a indelible marker pen to avoid confusion with new grown leaves.

One day after foliar application of abamectin, the treated leaves were removed from the plants and introduced into petri-plates as previously described. The same procedure was done on day 7, day 14 and day 21 after treating the plants with abamectin. Ten adults of $T$. urticae were carefully placed on each leaf. Five replicates per treatment were used.

Statistical analysis. Mortality was corrected using Abott's correction formula (Abbott, 1925). All data in each experiment were evaluated using analysis of variance. Significant differences among means were detected by Newman-Keul's test at $\mathrm{P}<0.05$. All statistical analyses were made using the Statistical Package for Social Scientists (SPSS) 13.0

\section{RESULTS}

Direct acaricide efficacy. Abamectin efficacy against $T$. urticae differed significantly in terms of concentrations of this acaricidal product. Overall, $100 \%$ mortality was obtained when the recommended dose (9 ppm) was applied (Table 1). There was a high knock-down effect after 24 hours of exposure to 5 or $7 \mathrm{ppm}$ of abamectin.

Significant differences existed among bifenthrin doses against $T$. urticae. High mortality of $T$. urticae was not observed when the recommended dose of bifenthrin was applied $(50 \mathrm{ppm})$. Three times the recommended dose of bifenthrin (150 ppm) was necesssary to obtain $75 \%$ of mortality (Table 1). Bifenthrin was considerably less toxic on $T$. urticae than abamectin.

Doses of abamectin showed different toxicities on predacious mite P. persimilis. Abamectin was considerably less toxic on predatory mites $P$. persimilis than on phytophagous ones, $T$. urticae. Thus, the recommended dose of this product $(9 \mathrm{ppm})$ presents high activity on $T$. urticae with all individuals dying, whereas it is harmless to $P$. persimilis: only $47 \%$ of this predatory mite were killed at this dose (Table 2). Furthermore, application at quarter the recommended dose (2 ppm) was toxic to T. urticae, whereas it was not against $P$. persimilis, where 2 ppm of abamectin caused $54 \%$ mortality in $T$. urticae vs. only $2 \%$ in P. persimilis.

Residual acaricide efficacy. Abamectin efficacy against $T$. urticae varied significantly with duration of exposure to this acaricide (Table 3). The efficacy against $T$. urticae was the most important during the first 7 days after the initial treatment. A significant decrease in toxicity was observed 14 days after the start of treatment. Approximately 54\% mortality was obtained 14 days after foliar application of the abamectin recommended dose (9 ppm). Twenty one days after application of this dose, only 37\% mortality was observed. The recommended dose of abamectin persisted for much longer than lower doses (7 or 5 ppm). When 5 ppm of abamectin was applied, only $16 \%$ of $T$. urticae was dead at day 21 (Table 3).

TABLE 1. Mortality of $T$. urticae exposed for $24 \mathrm{~h}$ to bean plants after abamectin and bifenthrin treatments

\begin{tabular}{lcc}
\hline Treatment & Doses $(\mathrm{ppm})$ & Mortality $(\%)$ \\
\hline Abamectin & 2 & 54 \\
& 3 & 62 \\
& 4 & 66 \\
& 5 & 78 \\
& 7 & 83 \\
Bifenthrin & 9 & 100 \\
& 15 & 23 \\
& 25 & 32 \\
& 50 & 40 \\
& 75 & 49 \\
& 100 & 59 \\
& 125 & 67 \\
& 150 & 75 \\
\hline
\end{tabular}


TABLE 2. Mean percentage mortality of $P$. persimilis exposed for $24 \mathrm{~h}$ to bean plants after abamectin treatment

\begin{tabular}{cc}
\hline Doses (ppm) & \% mortality \\
\hline 2 & 2 \\
3 & 3 \\
4 & 11 \\
5 & 19 \\
7 & 37 \\
9 & 47 \\
\hline
\end{tabular}

TABLE 3. Mean percentage mortality of $T$. urticae exposed for $24 \mathrm{~h}$ to bean plants $1,7,14$ or 21 days after abamectin treatment

\begin{tabular}{lcccc}
\hline $\begin{array}{l}\text { Doses } \\
\text { (ppm) }\end{array}$ & \multicolumn{4}{c}{ Days after application } \\
\cline { 2 - 5 } & 1 day & 7 days & 14 days & 21 days \\
\hline 5 & 85 & 55 & 38 & 17 \\
7 & 89 & 60 & 44 & 28 \\
9 & 94 & 67 & 54 & 37 \\
\hline
\end{tabular}

\section{DISCUSSION}

Abamectin application effectively controls mites. T. urticae exposed to the recommended dose of abamectin suffered $100 \%$ mortality. Such high effectiveness of abamectin against two-spotted spider mite in strawberry was also observed in several other crops like cotton, cucumber, ornamental plantes (Andrei, 2005; Duchovskiene, 2007).

Bifenthrin was much less toxic to T. urticae. Only $40 \%$ of mortality was registred when recommended dose of bifenthrin (50 ppm) was applied. Such a mild effectiveness could be due to intensive applications of bifenthrin in strawberry fields. In fact, this product had been intensively used in the Loukkos region during the last ten years resulting in the possibility of resistance development. Such an observation was also made by Ay and Gurkan (2005), who reported that bifenthrin became ineffective for controlling pests in the field, possibly due to resistance development. Due to the fact that most pyrethroids used against the mite were also used against other pests, T. urticae was strongly selected for resistance by the increased application of these pesticides (Herron et al., 2001).

One of the strategies for preserving the effictiveness of abamectin is to minimise the number of foliar sprays applications. For this reason, it was important to evaluate the residual activity of abamectin against $T$. urticae. The results obtained indicate an effective control of T. urticae after approximately 2 weeks of foliar application. The toxicity of abamectin gradually declined after 14 days post-application. This corroborates with similar findings by Duchovskiené (2007), who reported that abamectin reduces the number of T. urticae and is highly efficient 3-14 days after application. On the other hand, we showed that the persistence of abamectin efficacy depends on the dose applied. Thus, we observed that approximately $37 \%$ of $T$. urticae population was killed three weeks after application of the recommended dose (9 ppm). At applied lower concentrations of abamectin ( 5 or $7 \mathrm{ppm}$ ), we observed faster decline in product residual activity. Thus, it is advisable to apply abamectin at the recommended dose to reduce the number of its foliar applications.

In view of growing interest in the use of phytoseiid predators as biological control agents, it is essential to consider the effects of acaricide applications for conserving resident predator populations. In the present work, we evaluated the effects of abamectin against $P$. persimilis. From this study, this product is less toxic to predatory mite $P$. persimilis than to their pest prey T. urticae. Thus, the use of the recommended dose (9 ppm) causes only $47 \%$ of mortality in $P$. persimilis; whereas it is able to eliminate all $T$. urticae individual (100\% of mortality). This corroborates with similar findings by Zhang and Sanderson (1990), who stated that, at concentrations of 0.08-16 ppm, abamectin did not significantly affect survival and mobility of $P$. persimilis, but reproduction was significantly reduced higher concentrations (8-16 ppm). They concluded that abamectin at selective sublethal concentrations could be of value in adjusting predator/prey ratios in integrated management of spider mite pest species. 


\section{CONCLUSION}

Abamectin appears to be a remarkably good fit for strawberry mite management because of its strong efficacy, the persistence of control and its limited negative impact on important natural enemies. It may be classified as IPM-compatible acaricide in integrated pest management programs against $T$. urticae infesting strawberry crops in Morocco.

\section{ACKNOWLEDGEMENTS}

We acknowledge the contribution of A. El Haddad., from Crop Protection Service (DPVCTRF) of Rabat, for his kind assistance in collecting mites in the Loukkos region of Morocco.

\section{REFERENCES}

Abbott, W. S. 1925. A method for computing the effectiveness of an insecticide. Journal of Economic Entomology 18: 265- 267.

Andrei, E. 2005. Compêndio de defensives agricolas. $7^{\text {a }}$ ed., Editora Andrei, São Paulo. 1141pp.

Ay, R. and Gurkan, M.O. 2005. Resistance to bifenthrin and resistance mechanisms of different strains of two-spotted spider mite (Tertanychus urticae) from Turkey. Phytoparasitica 33:237-244.

Cho, J. R., Hong, K.J., Choi, B.R., G. Lee, S., Lee, G.S., Yoo, J.K. and Lee, J.O. 1995. The inhibition effect of the twospotted spider mite population density by using the introduced predacious mite (Phytoseiulus persimilis Athias-Henriot) and effect of several pesticides to the predacious mites. RDA. Journal of Agricultural Science 37: 340-347.

Devine, G. J., Barber, M. and Denholm, I. 2001. Incidence and inheritance of resistance to METI-acaricides in European strains of the two-spotted spider mite (Tetranychus urticae) (Acari: Tetranychidae). Pest Management Science 57: 443-448.

Duchovskiene, L. 2007. Effects of abamectin on the two-spotted spider (Tetranychus urticae Koch) in Greenhouse cucumbers. Sodininkyste Ir Darzininkyste 26:166-175.
Herron, G.A., Rophail, J. and Wilson, L.J. 2001. The development of bifenthrin resistance in two-spotted spider mite (Acari: Tetranychidae) from Australian cotton. Experimental and Applied Acarology 25:301-310.

Hoy, M.A., Cunningham, G.L. and Knuston, L. 1983. Biological control of pests by mites. Univ. Calif. Div. Agric. Nat. Res. Publ., 3304, Berkeley, CA.

Kim, D.I., Lee, C.S., Paik, C.H., Kim, S.S. and Ma, K.C. 1997. Population fluctuation of Tetranychus Kanzawai and their natural enemies and related susceptibility of some pesticides to Amblyseius womersleyi and T. kanzawai. Journal of Korean Tea Society 3: 83-93.

Knight, A. L., Beers, E.H., Hoy, S.C. and Riedl, H. 1990. Acaricide bioassay with spider mites(Acari: Tetranychidae) on pome fruits: Evaluation of methods and selection of discrimination concentrations for resistance monitoring. Journal of Economic Entomology 83: 1752- 1760.

McMurtry, J. A. and Croft, B.A. 1997. Life-syles of phytoseiid mites and their roles in biological control. Annual Review of Entomology 42: 291- 321.

Sato, M. E., Marcos, Z., Da Silva, A., Dalton, R. and De Souza, M.F. 2005. Abamectin resistance in Tetranychus urticae Koch (Acari: Tetranychidae): Selection, cross-resistance and stability of resistance. Neotropical Entomology 34: 991-998.

Stumpf, N. and Nauen, R. 2001. Cross-resistance, inheritance and biochemistry of mitochondrial electron transport inhibitor-acaricide resistance in Tetranychus urticae (Acarie: Tetranychidae). Journal of Economic Entomology 94: 1577- 1583.

Van Lenteren, J. C. and Woets, J. 1988. Biological control and integrated pest control in greenhouses. Annual Review of Entomology 33: 239- 269.

Zhang, Z. Q. and Sanderson, J.P. 1990. Relative toxicity of abamectin to the predatory mite Phytoseiulus persimilis (Acari: Phytoseiidae) and two-spotted spider mite (Acari: Tetranychidae). Journal of Economic Entomology 83: 1783- 1790. 